\title{
PERANAN KEBIJAKAN PENDIDIKAN ISLAM DALAM MENGHADAPI PANDEMI COVID-19
}

\author{
Falih Sunnimadi ${ }^{1}$, Eni Riatul Malikhah ${ }^{2}$, Fery Diantoro ${ }^{3}$ \\ IAIN Ponorogo \\ sunnimadifalih@gmail.com,enhyshofiea16@gmail.com
}

\begin{abstract}
The Covid-19 pandemic has occurred in our beloved country Indonesia for almost a year. The emergence of the Covid-19 outbreak triggered various changes in various aspects of life, both in terms of social, health, education, and so on. In addition, the Covid-19 outbreak has led to the emergence of various new policies formulated by the government to break the chain of spreading Covid-19. This includes policies in the education sector. In accordance with the policy issued by the Ministry of Education and Culture, that in order to break the chain of the spread of the Covid-19 outbreak, teaching and learning activities at various levels of education are carried out online (online) and offline (outside the network). This is something new in our world of education. Which is usually the teaching and learning process carried out directly. Now, when the Covid-19 pandemic has to be done with the internet media or referred to as online (in the network). With the existence of this policy, it is a challenge for teachers and students as actors of education, especially in areas that lack technology and internet networks.This challenge applies to all teachers of educational institutions, including teachers under Islamic education institutions.
\end{abstract}

Keywords: Education Policy, Islamic Education

\begin{abstract}
Abstrak : Wabah Pandemi Covid-19 sudah hampir satu tahun terjadi di negara kita tercinta Indonesia. Kemunculan wabah Covid-19 memicu terjadinya berbagai perubahan dalam berbagai aspek kehidupan, baik dari segi aspek sosial, kesehatan, pendidikan, dan lain sebagainya. Selain itu, dengan adanya wabah Covid-19 ini menyebabkan munculnya berbagai kebijakan-kebijakan baru yang disusun oleh pemerintah guna memutus mata rantai penyebaran Covid-19. Termasuk di dalamnya yaitu kebijakan dalam sektor pendidikan. Sesuai dengan kebijakan yang dikeluarkan oleh Kemendikbud, bahwa demi memutus mata rantai penyebaran wabah Covid-19 kegiatan belajar mengajardiberbagai jenjang pendidikan dilaksanakan secara daring (dalam jaringan)dan luring (luar jaringan). Hal ini menjadi sesuatu yang baru dalam dunia pendidikan kita tentunya. Yang mana biasanaya proses belajar mengajar dilakukan secara langsung. Kini, pada saat pandemi covid-19 dengan terpaksa harus dilakukan dengan menggunakan media internet atau disebut dengan istilah daring (dalam jaringan). Dengan adanya kebijakan tersebut menjadi tantangan tersendiri bagi guru dan siswa sebagai pelaku pendidikan, terutama di daerah-daerah yang minim teknologi dan jaringan internet. Tantangan tersebut berlaku bagi semua guru lembaga pendidikan, tak terkecuali para guru dalam naungan lembaga pendidikan Islam.
\end{abstract}

Kata Kunci: Kebijakan Pendidikan, Pendidikan Islam 


\section{PENDAHULUAN}

Pendidikan merupakan sebuah pondasi dari sebuah peradaban, sehingga kualitas peradaban suatu wilayah tergantung juga dari kualitas pendidikannya. Pendidikan merupakan kunci pembangunan sumber daya manusia. Kualitas sumber daya manusia merupakan kunci terwujudnya Indonesia Emas 2045, yang adil dan sejahtera, aman dan damai, serta maju dan mendunia.

Sejak awal tahun 2020 perubahan drastis di bidang pendidikan mengalami revolusi. Pembelajaran yang tadinya didominasi oleh pembelajaran tatap muka beralih dengan pembelajaran dalam jaringan (daring) di semua jenjang pendidikan, termasuk perguruan tinggi. Guna mencegah penyebaran virus Covid-19, kebijakan pendidikan banyak dilahirkan. Sesuai dengan surat edaran yang diterbitkan Mendikbud Nomor 3 Tahun 2020 tentang pencegahan Covid-19 pada satuan pendidikan dan Nomor 36926/MPK.A/HK/2020 tentang pembelajaran daring, para pendidik diharapkan menghadirkan proses pembelajaran menyenangkan bagi siswa. ${ }^{1}$

Secara empirik realisasi kebijakan tersebut sangat bergantung pada berbagai faktor. Pertama, pemerintah pusat harus menjamin dengan menyediakan koneksi internet yang lancar dan stabil, subsidi kuota, bantuan perangkat digital, dan peningkatan kapasitas digital juga meminimalisir ketimpangan akses di berbagai wilayah. Harus ada anggaran alokasi anggaran secara khusus untuk mendukung lancarnya kegiatan pembelajaran daring tersebut. Pembelajaran daring tidak dapat dilakukan jika sekolah maupun orang tua tidak memiliki kapasitas memadai untuk mengakses perangkatnya. Pembelajaran ini tidak dapat terjadi ketika guru dan siswa sama-sama tidak memiliki komputer, handphone, atau kuota dan jaringan internet yang memadai. Beruntung, belakangan pemerintah membolehkan anggaran dana BOS untuk mendukung pelaksanaan pembelajaran secara daring.

Karena pentingnya pendidikan, maka dalam keadaan bagaimanapun pendidikan harus selalu diusahakan untuk berjalan dengan baik. Sehingga pemerintah mengeluarkan

${ }^{1}$ Jeffry Handika dkk, Pembelajaran Sains di Era Akselerasi Digital, 2020, Magetan: Jawa Timur: CV. AE MEDIA GRAFIKA, 1-2. 
kebijakan-kebijakan seperti pembelajaran jarak jauh dan kebijakan lain untuk mengupayakan pendidikan di Indonesia terus berjalan. ${ }^{2}$

\section{PERANAN KEBIJAKAN PENDIDIKAN ISLAM YANG ADA DI INDONESIA PADA MASA PANDEMI COVID-19}

Pendidikan Indonesia saat ini dihadapkan kebijakan pembelajaran jarak jauh setelah adanya ketetapan oleh Mendikbud yang mana pembelajaran harus dilaksanakan serentak secara daring di seluruh Indonesia, guna mengantisipasi penularan Covid-19. Hal tersebut mengacu berdasarkan surat edaran Menteri Pendidikan dan Kebudayaan Nomor 36962/MPK/HK/2020 tentang pembelajaran secara daring (dalam jaringan) dan bekerja dari rumah untuk mencegah penyebaran Covid-19. Konsekuensi dari kebijakan tersebut lembaga pendidikan mengganti pembelajaran luring dengan daring (Arora \&Srinivasan, 2020). Dalam surat edaran tersebut, Mendikbud juga menyarankan adanya pemanfaatan ari sebuah ilmu teknologi sebagai alat belajar mengajar agar dapat efektif dan efisien nantinya. Pemanfaatan teknologi tersebut dilakukan karena pembelajaran dilakukan secara jarak jauh. Adapun pembelajaran jarak jauh merupakan pembelajaran yang dilaksanakan dengan tidak bertatap muka secara langsung antara pengajar dan peserta didik, akan tetapi tetap dapat dibantu dengan menggunakan media untuk melakukan aktivitas proses belajar mengajar dengan sebagaimana mestinya dari yang sudah disarankan oleh kemendikbud. (Prawiyogi, dkk: 2020).

Kebijakan pembelajaran jarak jauh itu sendiri tentunya menjadikan tantangan tersendiri bagi Pendidik Agama Islam untuk melakukan pembelajaran dengan menggunakan teknologi. Bahkan pendidik pada pembelajaran jarak jauh dituntut siap untuk melakukan pembelajaran daring secara efektif kepada peserta didik dan memiliki kreativitas dalam proses mengajar (Suharwoto, 2020). Pembelajaran jarak jauh mengajarkan guru harus cepat merespon untuk siap tanggap terhadap perubahan serta belajar memahami perkembangan teknologi digital pada saat ini.

${ }^{2}$ Widya Sari dkk, Analisis Kebijakan Pendidikan Terkait Implementasi Pembelajaran Jarak Jauh pada Masa Darurat Covid-19, (Fakultas Tarbiyah, IAIN Bone), 2-3. 
Pada dasarnya guru pada masa kini tidak bisa mengabaikan teknologi sebagai enabler dalam proses pembelajaran. Revolusi industry 4.0 telah membawa dampak besar dalam kehidupan khususnya pendidikan (Joenaidy, 2020). Teknologi dari masa ke masa telah telah memberikan peluang-peluang baru untuk memudahkan manusia dalam berinteraksi bahkan dapat dijadikan perangkat dalam proses belajar mengajar. Pemanfaatan teknoloogi ini akan bermanfaat untuk mendukung aspek pedagogik dan konten pembelajaran yang disajikan dalam bentuk apapun. Pembelajaran jarak jauh ini menjadi katalisator guru untuk melakukan inovasi pembelajaran dan belajar menggunakan serba digital. Dengan demikian guru harus menguasai teknologi agar pembelajaran jarak jauh dapat dilakukan secara optimal.

Selain dari guru yang berperan dalam proses pendidikan sebagai penerapan kebijakan pendidikan islam, ada peran orang tua yang juga harus mendukung kebijakan pendidikan islam yang ada di Indonesia pada masa pandemic ini, apa yang harus dilakukan oleh orang tua?, yang harus dilakukan orang tua sebagai pendukung kebijakan pendidikan islam ini orangtua haruslah memiliki peran aktif didalamnya dalam mengawasi anak untuk benar-benar serius, membantu memfasilitasi semampunya untuk anak agar anak bisa belajar dengan nyaman dan maksimal walau berada dalam kondisi pembelajaran dari rumah, orangtualah yang berperan aktif untuk mengawasi langsung kepada sang anak agar kebutuhan belajarnya selalu terpenuhi. Dengan demikian pendidikan islam dimulai sejak dini maka peran orangtua dalam memberikan pendidikan agama islam dalam keluarga menjadi factor utama untuk perkembangan pemahaman islam pada anak, karena Pendidikan dalam keluarga berjalan sepanjang masa, melalui proses interaksi dan sosialisasi didalam keluarga itu sendiri. Esensi pendidikannya tersirat dalam integritas keluarga, baik didalam komunikasi antara sesama keluarga, dalam tingkahlaku keseharian orang tua, dan keluarga lainnya, juga dalam hal-hal lainnya yang berjalan dalam keluarga semuanya merupakan proses pendidikan bagi anak-anak. Oleh karena itu orang tua harus selalu memberikan contoh tauladan yang baik bagi anak-anak mereka, karena apapun kebiasaan orang tua di rumah akan selalu dilihat, dicerna dan bahkan sampai akan diritu oleh anak-anak.

Tafsir menyebutkan, pendidikan dalam keluarga merupakan pendidikan pertama dan utama bagi anak-anaknya (Abdillah, 2017). Dikatakan pertama karena memang anak 
mendapatkan pendidikan pertama kali di lingkungan keluarga, yakni orang tua, ayah dan ibunya. Sementara dikatakan utama karena yang paling utama mendidik anak adalah orang tua (Lahmi, 2016). Dari interaksi dalam keluarga inilah anak-anak memperoleh pengetahuan, keterampilan, nilai-nilai, dan sikapnya dalam hidup dan dengan itu pulalah mereka memperoleh ketenangan dan ketentraman hidup.

Keberadaan keluarga bukan hanya penting bagi seorang individu tetapi juga bagi masyarakat, sehingga masyarakat menganggap keluarga sebagai institusi sosial penting dan merupakan unit sosial yang utama melalui individuindividu yang telah dipersiapkan didalamnya, baik berupa kebudayaan, nilainilai, kebiasaan, maupun tradisi yang ada didalamnya (González Zarandona et al., 2017). Dari segi inilah, maka keluarga dapat menjadi ukuran dalam sebuah masyarakat, dalam arti apabila masingmasing keluarga berada dalam keluarga yang sehat, maka akan sehatlah suatu masyarakat, dan begitu pula sebaliknya, jika keluarga itu tidak sehat, maka dampaknya terhadap keluarga pun akan menjadi tidak sehat (Hidayatulloh, Halimi, 2013).

Bertugas sebagai pendidik dalam keluarga adalah ayah dan ibu. Merekalah yang memiliki tugas dan tanggung jawab pertama dalam mendidik anakanaknya di rumah. Ayah dan ibu berkewajiban memberikan asuhan, arahan, dan bimbingan kepada anak-anaknya. Orang tua merancang berbagai aturan yang harus dipenuhi oleh anakanaknya di rumah walaupun tidak tertulis.

Pendidikan yang ditanamkan kepada anak-anak sebagaimana dikatakan oleh Ulwan adalah pendidikan keimanan, pendidikan moral, pendidikan intelektual, pendidikan jasmani, pendidikan sosial dan kepribadian, dan pendidikan seksual. Semua itu merupakan tanggung jawab orang tua sebagai guru bagi anak-anak mereka (Menchik, 2014). Akan tetapi, dari hal itu semua, pendidikan yang paling pertama adalah pendidikan keimanan dan ketakwaan kepada Allah atau pendidikan agama. Karena pendidikan agama berperan besar dalam membentuk pandangan hidup seseorang. Oleh karena itu, pendidikan agama - dalam pandangan Islam diberikan ketika anak sejak dalam kandungan pendidikan prenatal (Dewi, 2012).

Anak merupakan amanah yang harus dijaga, dan dipertanggungjawabkan. Jelas tanggung jawab orang tua terhadap anaknya sangatlah besar. Secara umum, tanggung jawab itu terletak dalam penyelenggaraan pendidikan bagi anak dalam keluarga. Allah SWT, Tuhan yang Maha Esa, memerintahkan agar setiap orang tua menjaga 
keluarganya dari siksa api nereka. "Jagalah dirimu dan keluargamu dari siksa api neraka" (QS 66: 6).

Selain itu, pelaksaan pendidikan dalam keluarga karena orang tua berkeinginan anakanak tumbuh dan berkembang secara maksimal, baik perkembangan jasmani, ruhani. Kelak anak-anak menjadi anak yang sehat, kuat, cerdas, pandai, memiliki keterampilan dan juga yang terpenting adalah memiliki keimanan dan ketakwaan yang kuat. Semua orang tua tentu tidak ingin anak-anaknya tumbuh menjadi anak yang lemah baik fisik maupun mentalnya, lemah pengetahuannya (bodoh), dan juga tidak nakal (tidak melanggar aturan).

Karena berbagai keterbatasan, baik yang telah diberlakukan oleh pemerintah juga diliburkannya sekolah, pondok pesantren dan juga lembagalembaga pendidikan alQuran, juga tidak tertngal diberbagai instansi lainnya. Peran dan tanggung jawab orang tua, dalam mengantikan posisi guru maupun ustad. Maka banyak orang tua yang beralih profesi menjadi guru dan ustad guna melangsungkan pendikan putra putriya yang di kerjakan dirumah baik setiap pagi hari dan setiap sore hari.

Bukan hanya sekedar mencari nafkah guna memenuhi kebutuhan sang buah hati, kedua orang tua juga menjadi sebagi guru dan juga sebagai teman yang mengajar anak-anaknya di rumah di masa pandemi yang sedang berlangsung. Tidak jarang orang tua merasa kesulitan dan kebingungan dalam memberikan pemahaman dan pembelajaran kepada anak-anaknya.

Orang tua adalah pendidik dalam rumah tangga bagi anak-anaknya, karena dari merekalah anak pertama kali mendapatkan pendidikan. Orang tua harus sadar bahwa anak adalah amanah yang akan dimintai pertanggungjawaban di akhirat, sehingga anak tidak cukup diberi materi yang sifatnya lahiriyah, tapi anak juga wajib diberikan materi rohaniyah

Dengan demikian, tujuan adanya pendidikan agama dalam keluarga adalah terbentuknya insan-insan yang beriman dan bertaqwa kepada Allah Subhanahu W a Ta'ala, serta berakhlak mulia yang mencakup etika, moral, budi pekerti, serta mengamalkan nilai-nilai agama dalam kehidupan sehari hari baik di lingkungan keluarga dan masyarakat.

Di samping itu juga tujuan dari pendidikan agama dalam keluarga ialah agar anak mampu berkembang maksimal baik jasmani, rohani maupun akalnya. Menjadi anak- 
anak yang shalih dan shalihah. Termasuk tujuan dari pentingnya pendidikan agama dalam keluarga adalah tercapainya keluarga yang sakinah waddah wa rahmah, rumah yang menjadi surga bagi para penghuninya, baik surga dunia maupun sebagai penghantar menuju surga akhirat. ${ }^{3}$

\section{TANTANGAN YANG HARUS DIHADAPI PADA MASA PANDEMI COVID-19}

Pembelajaran jarak jauh bagi guru maupun siswa merupakan tantangan besar. Tantangan bagi guru adalah bagaimana mampu mengajarkan siswanya yang memiliki kecerdasan dan penangkapan yang berbeda-beda, gaya belajar yang beraneka ragam, serta solutif ketika siswanya mengalami hambatan dalam proses pembelajaran jarak jauh. Hal tersebut bisa menjadi peluang guru untuk memahami kondisi dan situasi murid serta melakukan tindakan yang tepat untuk memberikan pengajaran maupun pelayanan. Sehingga disinilah guru memiliki tantangan dan peluang untuk mempelajari teknologi baik visual maupun audio visual.

Adapun menurut penelitian yang dilakukan oleh Suci Febriyantika Rahman menyebutkan bahwa ada beberapa problematika yang dialami dalam pelaksanaan pembelajaran daring antara lain:

1. Faktor pendidik

2. Keterbatasan sarana dan prasarana

3. Penguasaan teknologi yang masih rendah

4. Kurangnya keefektifan belajar mengajar

5. Faktor peserta didik

6. Kurangnya melakukan budaya literasi

7. Tingkat pemahaman agama yang berbeda-beda

8. Kemauan siswa yang rendah untuk belajar

9. Keberagaman pengetahuan siswa yang berbeda-beda

10. Lingkungan keluarga

3 Achmad, Wahyudi. Peran dan tantangan pendidikan agama islam di era pandemic covid 19 pada lingkungan keluarga, http://www.ejournal.stitmuhbangil.ac.id/index.php/jie JOURNAL OF ISLAMIC EDUCATION Vol. 5 No. 2 Nopember 2020. 175-178 


\section{Lingkungan masyarakat ${ }^{4}$}

Selain beberapa tantangan di atas ada beberapa tantangan yang dirasakan oleh guru pendidikan Agama Islam. Di antaranya peran guru yang tidak dapat tergantikan dengan teknologi. Karena guru adalah pendidik yang mentranfer ilmu pengetahuan sekaligus nilai-nilai akhlakul karimah.

Seorang guru tidak sama dengan teknologi yang hanya memberikan pengetahuan saja. Akan tetapi, seorang guru juga menjadi teladan bagi muridmuridnya dan hal tersebutlah yang tidak dapat tergantikan oleh teknologi sampai kapanpun. Selain itu, tantangan yang dirasakan guru pendidikan Agama Islam adalah terkait metode dan materi ajar. Materi ajar dalam mata pelajaran agama Islam adalah materi yang berkaitan dengan keyakinan, keimanan, dan praktik-praktik ibadah. Agar materi tersebut dapat tersampaikan dengan efektif maka, diperlukan metode yang tepat dalam menyampaikannya seperti dengan menggunakan metode ceramah, diskusi, tanya jawab, praktik, dan lain sebagainya. Dalam pembelajaran secara daring tentu metode-metode tersebut tidak dapat dilakukan secara maksimal. Maka di sinilah tantangan seorang guru pendidikan agama Islam untuk menciptakan metode baru yang sesuai dengan kondisi saat ini.

Dalam pembelajaran pendidikan agama islam selama daring terdapat banyak tantangan yang menuntut guru untuk lebih aktif dan kreatif ketika memberikan penjelasan kepada siswa. Misalnya, materi rukun iman dan lain sebagainya.

\section{REALISASI DAN IMPLEMENTASI KEBIJAKAN PENDIDIKAN ISLAM DI MASA PANDEMI COVID-19}

Dari beberapa peranana kebijakan yang telah dilahirkan oleh pemerintah yang berwujud keputusan secara hukum dan tentunya ada tantangan yang harus dihadapi, maka perlu adanya realisi dan implementasinya di masa pandemic ini, walaupun pada wilayah perkotaan yang notabene adalah wilayah yang sudah cukup maju dan mendukung untuk pelaksanaan pembelajaran secara daring, kebijakan pemerintah

${ }^{4}$ Suci Febriyantika Rahman, Problematika Pembelajaran Pendidikan Agama Islam (PAI) pada Masa Pandemi Covid-19 di SMP Islam Nurussalam al-Khoir Mojolaban Sukoharjo, (Srikpsi UMS, 2020), 8-12. 
tersebut dapat direalisasikan dengan relatif baik. Sebaliknya, di wilayah pedalaman dan terpencil yang notabene kurang dalam hal sarana dan prasana pendukung pembelajaran daring, kebijakan pemerintah tersebut sangat sulit untuk terealisasikan.

Maka dari itu, sistem Pendidikan Agama Islam dalam upaya membentuk peserta didik berkualitas bergantung pada:

1. Raw input (calon peserta didik).

Aspek raw-input ini dipengaruhi oleh dua faktor, yaitu: latar belakang keluarga dan lingkungan socialraw-input.

2. Process. Aspek proses ini bergantung pada beberapa aspek:

a. pendidik yang profesional,

b. kelas yang representatif,

c. sarana yang memadai, dan

d. inovasi kurikulum. Faktor penunjang proses pembelajaran ini dapat melahirkan pembelajaran efektif dan peserta didikberkualitas.

3. Output (lulusan).Lulusan yang dikehendaki dalam pendidikan dan pembelajaran, termasuk pembelajaran PAI, lulusan unggul, berprestasi yang holistik. Unggul, berprestasi, holistik ini dalam pendidikan Islam disebut orang yang dapat memelihara diri.

Sistem pendidikan dalam konteks Pendidikan Agama Islam, berlaku dalam situasi dan kondisi apapun, termasuk di tengah pandemi Covid-19. terdapat faktafakta menarik untuk merealisasikan kebijakan pendidikan islam dari ruang pendidikan di masa pandemi Covid-19, yaitu:

1. Pendidikan dilaksanakan tidak di ruang kelas, melainkan di ruang isolasi (rumah). Pembelajaran di ruang isolasi ini bagian dari kebijakan socialdistancingsehingga interaksi fisik tidak terjadi dalam memutus pandemi Covid-19 secara masif. Pendidikan Agama Islam dilihat dariorientasinya memelihara manusia secara fisik agar tetap bugar dan sehat. Ini berarti pendidikan di ruang isolasi merupakan ikhtiar agar upaya pemeliharaan diri tetap berjalan sesuai sistem dan mekanisme Pendidikan Agama Islam. Ini 
wilayah raw input. Ruang keluarga dan ruangkehidupan socialmenjadi penyangga pemeliharaan diri.

2. Pendidikan dilaksanakan dengan bimbingan jarak jauh dan memanfaatkan teknologi informasi (IT) sebagai pengganti tatap muka. Menarik di sini, pendidikan yang dilaksanakan di rumah bukan menghentikan proses pendidikan, melainkan memindahkan sementara ruang belajar. Pendidikan di tengah pandemi Covid-19 harus diterjemahkan sebagai tantangan kreatif para pendidik profesional untuk tetap berkarya, berkreasi, berinovasi. Pendidikan di tengah pandemi Covid-19 harus menjadikan aktivitas pembelajaran efektif. Proses pendidikan di tengah pandemi Covid-19 tetap bertujuan memelihara jiwa peserta didik.

3. Pendidikan dilaksanakan untuk menciptakan peserta didik yang berkualitas. Itulah fenomena di tengah pandemi Covid-19 peserta didik tetap belajar di ruang isolasi, mempelajari mata pelajaran seperti di sekolah di bawah bimbingan pendidik profesional. Pelaksanaan PAI ini dapat menghasilkan output berkualitas.

4. Pelaksanaan pendidikan praktis melalui gerakan masif kebersihan dalam seluruh dimensinya. Pertama, kebersihan fisik. Fisik manusia bagian dari wadah eksistensi manusia yang perlu dipelihara dan dirawat. Itulah alasan pemeliharaan di masa pandemi Covid-19manusia diharuskan menutup hidung dan mulut agar fisiknya terpelihara dari penyakit yang keluar dari mulut manusia. Lingkungan tempat hidup manusia harus dipelihara sehingga interaksi berjalan aman dan nyaman. Itulah arti penting gerakan kebersihan pakaian danlingkungan tempat tinggal di masa pandemi Covid-19. Kebijakan sekaligus gerakan social distancingbagi bangsa Indonesia merupakan refleksi dari pelaksanaan kebijakan Pendidikan Agama Islam dalam rangka pemeliharaan diri. ${ }^{5}$

${ }^{5}$ Basri Hasan dkk, Pendidikan Agama Islam dan pemeliharaan diri (Hifdz. An-Nafs) di tengab wabah virus corona, ( Pendidikan Agama Islam, UIN SUnan Gunung Djati Bandung), 5. 


\section{KESIMPULAN}

Pandemi Covid-19 (CoronaVirus Dease) yang telah menimpa sebagian besar negara di dunia telah memberikan dampak yang begitu besar bagi kehidupan manusia. Tak terkecuali di Indonesia, Covid -19 juga berdampak pada berbagai aspek kehidupan termasuk pada dunia kependidikan. Pendidikan di Indonesia yang biasanya dilakukan secara langsung/ tatap muka. Karena adanya wabah pandemi Covid-19 ini, pembelajaran dilaksanakan secara daring (dalam jaringan). Hal tersebut sesuai dengan kebijakan yang dikeluarkan Mendikbud dalam SE Mendikbud Nomor 36962/MPK/HK/2020 . Hal ini tentu merupakan sesuatu yang baru, yang menjadi tantangan bagi pelaku pendidikan di Indonesia. Tak terkecuali pendidik agama Islam. Tantangan dalam pelaksanaan pembelajaran secara daring (dalam jaringan) dirasakan oleh semua pihak, baik guru maupun murid. Banyak hal yang perlu dipersiapkan untuk melaksanakan kegiatan pembelajaran secara daring. Diantaranya, penguasaan teknologi informasi, adanya sarana pembelajaran daring (seperti handphone atau laptop), adanya kuota dan jaringan internet yang memadai, dan kesiapan materi ajar online. Hal tersebut tentu menjadi tantangan yang sangat besar terlebih bagi para pendidik yang sepuh dan bagi para siswa yang berada di wilayah minim sinyal internet.

Adapun realisasi dari kebijakan yang dikeluarkan oleh Mendikbud tentang pelaksanaan pembelajaran secara daring berbeda-beda di berbagai wilayah Indonesia. Di wilayah perkotaan yang notabene adalah wilayah yang sudah cukup maju dan mendukung untuk pelaksanaan pembelajaran secara daring, kebijakan pemerintah tersebut dapat direalisasikan dengan relatif baik. Sebaliknya, di wilayah pedalaman dan terpencil yang notabene kurang dalam hal sarana dan prasana pendukung pembelajaran daring, kebijakan pemerintah tersebut sangat sulit untuk terealisasikan. 


\section{DAFTAR PUSTAKA}

Febriyantika Rahman, Suci. 2020. Problematika Pembelajaran Pendidikan Agama Islam (PAI) pada Masa Pandemi Covid-19 di SMP Islam Nurussalam alKhoir Mojolaban Sukoharjo. Srikpsi UMS.

Handika, Jeffry. Dkk. 2020. Pembelajaran Sains di Era Akselerasi Digital. Magetan: Jawa Timur: CV. AE MEDIA GRAFIKA.

Hasan, Basri dkk, 2020. Pendidikan Agama Islam dan pemeliharaan diri (Hifdz. An-Nafs) di tengah wabah virus corona, Pendidikan Agama Islam, UIN SUnan Gunung Djati Bandung.

Wahyudi, achmad. Peran dan tantangan pendidikan agama islam di era pandemic covid 19 pada lingkungan keluarga, http://www.ejournal.stitmuhbangil.ac.id/index.php/jie JOURNAL OF ISLAMIC EDUCATION Vol. 5 No. 2 Nopember 2020.

Widya, sari. Dkk. 2020. Analisis Kebijakan Pendidikan Terkait Implementasi Pembelajaran Jarak Jaub pada Masa Darurat Covid-19. Fakultas Tarbiyah, IAIN Bone 